УДК

\title{
South Ukraine Greek community under revolutionary upheavals and armed conflicts (1917-1920)
}

\section{O.P. Trygub ${ }^{1}$, O.V. Osypenko ${ }^{2}$}

\author{
${ }^{1}$ Petro Mohyla Black Sea National University \\ 1068 Desantnykiv Street, Mykolaiv, 54003, Ukraine \\ E-mail: alextrigub@ukr.net \\ ${ }^{2}$ Odessa National Maritime University \\ 34 Mechnikov Street, Odessa, 65029, Ukraine \\ E-mail: osupenkooleksandr@ukr.net
}

\section{Abstract}

The revolutionary changes of 1917 contributed to the intensification of the political, national, and cultural life of the Greek community of the entire Black Sea and Azov Sea coasts, where the national states emerged on the shards of the former Russian Empire. In contrast to the Azov Sea region, where the Greeks had an active social and political life and by the end of 1917 had formed the Mariupol Union of the Hellenic People, the Greeks of the Northern Black Sea region were quite apolitical and inactive. Their attitude to the Ukrainian and Soviet powers was rather ambiguous, and during 1917 they maintained, mainly, a wait and see position. Only individual representatives of the Greek people were affiliated with one or another party, which was more an exception than a typical feature of the Greek community. The Greeks fought in the ranks of the Imperial Army, N. Makhno's Rebel Army, in the Red Army, in regular units and partisan detachments of the Volunteer Army. In contrast to the rural population, which opposed the Volunteer Army and its policies, the urban communities of Odessa, Nikolaev, and Kherson actively supported both the French-Greek Entente troops and Denikin's Volunteer Army. Most urban Greeks were well-to-do middle-class persons running small and medium businesses (restaurants, hotels, grocery stores, various workshops, etc.) and did not accept the ideas of social and property equality proclaimed by the Bolsheviks. The article draws on the periodical press and undefined documents of the Soviet Special Services to define the role of the Greek communies of the Ukrainian Black Sea Region cities in the revolutionary events. The authors analyze the role of the Greek community mem- 
bers in the military and political events of 1917-1920 and their attitude to the changing powers, participation in the revolutionary struggle, the reasons for the emigration of 1919-1920, and Bolshevik repressions against the Greek ethnos. It is concluded that the Greek community of the Northern Black Sea region suffered the greatest losses as a result of mass emigration, rather than civil confrontation during the revolution time.

Keywords: revolution, Civil War, Greeks, Entente, South of Ukraine, Greek emigration, Red Terror.

\title{
Греческая община Южной Украины
}

в условиях революционных потрясений

и вооружённых столкновений

(1917-1920 гг.)

\author{
А.П. Тригуб ${ }^{1}$, А.В. Осипенко ${ }^{2}$ \\ 1 Черноморский национальный университет им. П. Могилы \\ Украина, 54003, г. Николаев, ул. 68 Десантников, 10 \\ E-mail: alextrigub@ukr.net \\ 2 Одесский национальный морской университет \\ Украина, 65029, г. Одесса, ул. Мечникова, 34 \\ E-mail: osupenkooleksandr@ukr.net
}

\section{Авторское резюме}

Революционные перемены 1917 г. способствовали активизации политической и национально-культурной жизни греческой общины всего Черноморско-Азовского побережья на почве создававшихся национальных государств на осколках бывшей Российской империи. В отличие от Приазовья, греки Северного Причерноморья были достаточно аполитичны и малоактивны. Отношение их как к украинской, так и к советской власти было достаточно неоднозначным, и в течение 1917 г. они сохраняли преимущественно выжидательную позицию. Лишь отдельные представители греческого народа примыкали к тем или иным партиям. В противоположность сельскому населению, которое выступило против Добровольческой армии и её политики, городские общины активно поддержали как французско-греческие войска Антанты, так и Добровольческую армию Деникина. Большинство городских греков были зажиточными мещанами,держали мелкий и средний бизнес и не воспринимали идей социального и имущественного равенства, провозглашавшихся большевиками. В пу- 
бликации сделана попытка оценить место греческой общины причерноморских городов Украины в вихре революционных событий на основе периодической прессы и неизвестных документов советских спецслужб. Рассматривается роль греческой общины в военно-политических событиях 1917-1920 гг., анализируются отношение греков к сменявшимся властям, их участие в революционной борьбе, причины эмиграции 1919-1920 гг., большевистские репрессии по отношению к греческому этносу. Сделан вывод, что наибольшие потери греческая община Северного Причерноморья понесла в результате массовой эмиграции, а не гражданского противостояния времен революции.

Ключевые слова: революция, гражданская война, греки,Антанта,Южная Украина, греческая эмиграция, красный террор.

At the turn of the $20^{\text {th }}$ century, the Greeks of the Black Sea region cities lived in small national colonies with a rather high standard of living. Their main spheres of activity were commerce and banking, manufacturing, households, rent of real estate, transport and communications, public service, etc. At the same time, the percentage of the lower classes (servants, industrial workers, day laborers, and the poor) reached about $50 \%$ economically active Greek population [47: 48]. A significant stratum of the Greek diaspora were the peasants from villages and towns situated near large port cities. The total number of the Greek diaspora in the Northern Black Sea region, reaching about 35 thousand people, was formed as a result of migration waves from 1858 to 1918 [46: 222].

The revolutionary changes of 1917 contributed to the activation of the political, national, and cultural life of the Greek community of the entire Black Sea and Azov Sea coasts. In Odessa, the Greek community began publishing the weekly "Anagennisis" (Renaissance) edited by G. Alatsidis, and the independent political newspaper "Ilios" continued to be published. The latter was the national press organ of the Greeks of Russia (at the end of 1917 the newspapers ceased to exist).

Taking advantage of the general democratization of social and political life, on June 29 - July 10,1917, the first All-Russian Congress of the Hellenes took place in Taganrog, in which about 40 delegates took part, including those from Odessa. The All-Russian Union of Hellenes was created, and a decision was made to create political and democratic clubs and unions, which were to act as defenders of the political, national, and cultural interests of the Greek population. Those decisions did not have any success either in the organizational or political spheres [37:83-84].

Unlike the Azov Sea region, where the Greeks consolidated by the end of 1917 into the Mariupol Union of the Hellenic People, the Greeks of the Northern Black Sea region were quite apolitical. Their attitude 
to both the Ukrainian and Soviet authorities was rather ambiguous, and during 1917 they maintained, mainly, a wait and see attitude. The words of Nikolayev engineer Leonid Popandopulo are indicative in this respect: “...I met the October Revolution indifferently, neither hostilely, nor sympathetically. On the one hand, I believed that the phenomenon was temporary, no longer than 3-4 months, and the revolutionary wave would subside and a legal position would be established without any excesses, and on the other hand, I was little interested in politics as a foreign citizen and was on the sidelines" [10: 13].

Individual representatives of the Greek people affiliated with one or another party. Thus, Odessa resident Anton Yanopulo, being for a long time a member of the Socialist Revolutionary Party, in June 1917 joined the Bolsheviks and "began to campaign actively for the Bolshevik Party" [15: 18]. An active member of the Socialist Revolutionary Party was the Greek V.A. Iraklidi, who was a member of the editorial board of the Socialist Revolutionary Party newspaper "Revoliutsionnoe Delo" (Revolutionary Deed) [1:23].

Pro-Ukrainian sentiments did not pass by the Greek community either. A striking example is the fate of Nikolai Arkas (junior), the son of the famous Nikolayev public figure and educator N. Arkas. During the February revolution, N. Arkas was in military service with the rank of subaltern officer. On July 4,1917, he was appointed commander of the squadron, which in December 1917 was Ukrainized and renamed to a sotnia. In April 1918, the sotnia was reorganized into a cavalry battalion of the UNR army. During the Hetman coup, N. Arkas was one of the first to support Skoropadskiy, and with the coming to power of the Directory, he joined the Army of the Ukrainian National Republic and took part in battles against Denikin's volunteers. On December 11, 1919, together with the regiment, he joined the Ukrainian Galician Army, which at that time was in alliance with the Armed Forces of South Russia. Since 1920 he emigrated to Western Ukraine [41:18-19].

But such examples are more an exception than a peculiar feature of the Greek community. The vast majority of Greeks continued to go about their current affairs.

Some Greeks supported socialist ideas as well. In 1919 Stepan Buduris left for the village, gained 4 dessiatinas of land, and got a job as a secretary of the Revolutionary Committee [18: 18]. The sailor Leonid Iliopulos, inspired by the revolutionary events in Russia, fled to Odessa from Romania in 1917 with the crew of the barge, moved to Nikolayev, where he lived from that time on [6:13].

The October Revolution of 1917 and the subsequent first coming of the revolutionaries to power at the end of January 1918 led to the 
beginning of an anarchist rampage in such largest cities as Kherson, Nikolayev, and Odessa. The new power was characterized by censorship and the suppression of a number of newspapers, confiscations, change of the old administrative apparatus, arrests and executions of "counterrevolutionaries". Odessa bandits, using 'revolutionary mandates', broke into private houses, banks and counting-houses, shops, enterprises, and warehouses, where they demanded money and valuables [36:88,91]. But, despite this, most of the enterprises owned by the Greeks were kept safe.

In mid-March 1918, the situation changed due to the signing of the multilateral Treaty of Brest, according to which the Ukrainian National Republic was occupied by the Austro-German troops. From mid-March till early November 1918, everyone lived relatively calmly. On the other hand, with the strengthening of the power of Hetman Skoropadskiy and the Austro-German military command, the latter began to put things in order concerning the foreign citizens representing the Entente countries and their allies. As a result, on the basis of the order of the German commander-in-chief of all troops in Taurida and the Crimea, Robert von Kosch, dated July 24,1918 (his administrative responsibility included also Kherson county (uyezd) of Kherson Province (gubernia)), all Greeks were registered and controlled, and without the permission of the military commandant's office, they were prohibited to change their place of residence [27].

Consuls, who defended the interests of the Hellenes, always played an important role in the life of the Greek community. As of the beginning of 1917, in Kherson Province, the diplomatic representatives of Greece were in Odessa (consulate general) and Nikolayev (vice-consulate), which were headed by Consul General Emmanuel Kapsambeli and Vice-Consul Ivan Zigomala. On July 8, 1918, the occupation command suggested the entire staff of the Greek consulates to leave the territory of Ukraine. The protection of Greece citizens, as well as the guarding of the premises and archives of the consulates, was entrusted to the Dutch consul in Odessa Wilhelm Muntz [3; 33]. As a result, on July 19, the Greece diplomatic corps left Ukraine [32].

Despite such an attitude towards the Greek community, most of its representatives continued to be engaged in their own and public affairs. Some Greek traders even established trade relations with the occupation power, supplying foodstuffs and forage. Thus, Mikhail Stavriyani supplied grain to the Austro-Hungarian army in Odessa, buying it from the population of the local rural area [19: 10,17, 22], and the German army in Nikolayev was supplied by Angel Ikonomidi. The latter worked for a rich Nikolayev Greek grain merchant I. Kupp for a long time, where he saved up a fortune of 25 thousand rubles. The money in the bank 
was confiscated during the socialist requisitions in January - February 1918. Since the firm run by Kupp continued to work, the grain operations were conducted for all persons concerned [4:12].

The following events show the negative attitude of the Greek student youth towards revolutionary unrest. On the new tide of the revolutionary movement at the beginning of November 1918, the students of Novorossiya University made a decision to start a strike. In response, the Greek Student Society adopted a resolution declaring the strike to be detrimental and inopportune. As a result, the Council of Student Representatives decided to cease the student protest [39].

Events of the late 1918 - early 1919 in the international arena and in Ukraine led to the end of the short-lived Austro-German occupation. In December 1918 - January 1919, the French-Greek troops appeared in the cities of the Northern Black Sea region.

The Greek colony of Odessa held a special meeting on this matter, worked over a meeting ceremony, and appointed its representatives in the port: F. Kussis, P. Bebis, Iv. Saparis and I. S. Ksidias. The idea to meet guests at sea on a separate ship under the Greek flag was under discussion [28]. Local authorities appropriated up to 25 thousand rubles for the celebrations on the occasion of the arrival of the allies [26: 447]. The local press sang praises to the Entente troops.

On December 5,1918, Nikolayev met the representatives of the allied squadron. Among the representatives of local public institutions and local authorities, the Greek consul was also present [2].

The historian T. Kostopoulos noted that "at the lead of the solemn ceremonies of greeting the expeditionary corps were the elements of the old regime", and in Nikolayev "the Greek army was greeted only by the Greek consul with the elite of the Greek parish" [48].

At the beginning of November 1918, the Ministry of Foreign Affairs of the Ukrainian State called on all consuls who had left to return. Despite the "amnesty", the Greek diplomatic corps returned incomplete. Since E. Kapsambeli was appointed to The Hague, the duties of the consul in Odessa were performed by J. Georgiadi [13: 27, 35], while I. Zigomala returned to Nikolayev [38].

At the same time, the population gave the Greek expeditionary corps a rather cool reception. The Greek historian T. Kostopoulos pointed out in his report that "the soldiers felt a sense of being surrounded by an absolutely hostile population", since the workers of Odessa and Nikolayev "love Bolshevism... and are looking forward to the Reds". And even the inhabitants of the remote places "all had Bolshevik views" [49].

Unlike the majority of the population, who greeted the Greek army quite hostilely, the Greeks (except for the pro-Bilshovyk minded) 
treated the Greek contingent well. In Nikolayev, for example, in honor of the Greek contingent arrival, a magnificent dinner was arranged, one of the organizers of which was A. Ikonomidi, who supplied the army of his fellow countrymen with foodstuffs and was an interpreter at the Greek army headquarters. For his efforts, A. Ikonomidi got a merit certificate from the headquarters of the Greek troops "for the successful and proper supply of the troops with the foodstuffs" [4: 13-14].

On March 9,1919, the regular anniversary of the $7^{\text {th }}$ Athens Infantry Regiment establishment was solemnly celebrated in Nikolayev. A prayer service was held in the Greek Church, to which all the members of Nikolayev Greek colony were invited. Then a parade of Greek troops took place [24: 78; 42].

Despite the short stay of the Greek troops in Nikolayev (March 1-14, 1919), some Greeks managed to 'work' for the Greek counter-intelligence as well. For example, Dmitriy Margelis in 1937 testified that "when the city of Nikolayev was occupied by the Greek occupation forces, I took part in the work of the Greek counter-intelligence. As to the owner of a cafe-restaurant at that time, the residents of Nikolayev often came to me, whom I knew, that they supported the Soviet power and took part in Soviet demonstrations, so I immediately informed the state guards" [8: 8-9]. It should be mentioned that accusations of betraying communists to the occupation authorities were common among the execution sentences of the "Red Terror" period.

We must not forget about the pro-Bolshevik Greeks. The Bolsheviks paid great attention to the demoralization of the Entente troops and created in Odessa a special organization for subversive activities in the troops of the interventionists. It was called the "Foreign Collegium" and comprised national sections: French, Serbian, Polish, Romanian, and Greek. The Collegium arranged the spreading of proclamations and leaflets among the Greek soldiers in Odessa [36: 234]. In the book of the Greek historian K. Avgitidis [48], the copies of pro-Soviet leaflets in Greek spreading in Odessa in 1919 on behalf of the "Greek Communist Group of Odessa" are given as an appendix. Also in Odessa, several underground printing houses were publishing the newspaper "Communist" in Greek.

As a result, the French-Greek expeditionary contingent did not hold out in the South Ukraine cities for long. In March 1919 N. Grigoryev occupied the Black Sea region cities and approached Odessa. Not wanting to suffer casualties, the Bolsheviks agreed to allow civil and military evacuation from Odessa, which began on April 4 and lasted 3 days [46: 240-241]. 
Of course, the Greeks realized the danger of their position under Soviet rule, so they boarded ships with the Greek military and went abroad. This was promoted by the spreading rumors about the massacres committed by the men of Ataman Grigoryev. Ivan Bunin, after the surrender of Kherson and Nikolayev, wrote in his diary: "Rumors: The French are leaving Odessa... In Kherson, the Bolsheviks massacred up to 200 Greek families" [36: 239]. Many Greeks, abandoning real estate, left their homes. Only Odessa was left by 10-12 thousand Greeks [46: 241] (including refugees from the regions). Mostly those were wealthy Greeks who had the financial means for the trip. Of the entire Greek population, only $3 \%$ left for Greece. The overwhelming majority refused to leave their homes and remained in Soviet Russia [48: 290-291].

The remaining Greek population was taken under their protection by the consuls of other states. The Greeks of Nikolayev and Kherson were taken under his protection by the Danish consul in Nikolayev, about which he informed the Executive Committee of the Soviet of Workers' Deputies on March 28, 1919 [21]. In Odessa, the Dutch consul W. Muntz [46: 241] undertook the protective functions over the Greek colony.

The second advent of the Bolsheviks (March-August 1919) was marked by a bloody tragedy called the "Red Terror", carried out by the All-Ukrainian Extraordinary Commission (VUChK) and its local branches. The victims of the "famous" Odesa Extraordinary Commission, according to various sources, were from 1,000 to 2,000 executed [45: 116]. The number of people tortured in Kherson and Nikolayev has not been calculated for today, even approximately.

Having studied the available materials, we can say with confidence that the officials of Cheka did not carry out repressions on the ground of national origin, but focused on the class issue. In May 1919, for example, Spiridon Scarlato, a member of the underground organization "Russian People's-State Union" [35], was shot. As monarchists and counter-revolutionaries were shot: teacher Vladimir Frangopulo and staff captain Pavel Pitaki (Mitaki) [34; 43: 262; 44], the White officer Dionisius Papafanasopulo [17: 8-12,18]. In response to the "White Terror", the following people were shot during the "Red Terror": the houseowner Ivan Ambatelo, landowners Ksenofont Shurmuraki and Petro Dulanaki, Ivan Panayoti and his son Dmitriy Panayoti [29; 30; 43: 263-264]. Prince Dmitriy Mavrokordato managed to get free thanks to the support of the workers of the "Volunteer Fleet" shipping company, who came with a protest to the building of Odessa Cheka [23].

In Nikolayev on June 11,1919, the Greek Ivan Kuppa was arrested, but on June 14,1919, he was released because he settled for so-called 
"oblozhenie" (payment of a certain amount of money) [24:82-83]. Most likely, many of the remaining wealthy Greeks of the South of Ukraine cities simply paid off, agreeing to this form of 'cooperation' with the Bolsheviks. Our point of view is that the Greek diaspora, despite all the disadvantages of its position due to the intervention, escaped the expected massive repression. At the same time, all the Greeks were registered by the Foreign Affairs Department [22].

In the second half of August 1919, the region was taken under the control of the Volunteer Army headed by General Denikin. Some representatives of the Greek diaspora began to return along with the White Army. Odessa inhabitant Vladimir Sarlo told about his return: "In 1919, on March 21, I left with my mother for Greece to the city of Thessaloniki together with the retreating occupation Greek forces. The reason for the departure was the stampede of a part of the Greek population from Odessa, being afraid of the Soviet power revenge for the deeds of the occupation Greek troops and the anti-Soviet Greek population towards the Greeks. I returned to Odessa at the end of August 1919, when Odessa was occupied by the Whites" [16: 15]. Dmitriy Psaropulo told a similar story.

Angel Ikonomidi also fled from Nikolayev together with the units of the Greek troops and through Odessa got to Romania, from there he moved to Galati, and then moved to Constantinople. He stayed in Constantinople for about 4 months and in August 1919, having learned that Sevastopol was occupied by the White troops, he went there together with other Greeks who had fled from the Bolsheviks to Turkey. From Sevastopol,A. Ikonomidi returned to Nikolayev, where at that time were the volunteers of General Slashchov [4: 15, 24-25; 5: 9].

Almost all members of the Margelis family also returned to Nikolayev. Agreeing to the persuasions of the Greek Consul I.Zigomala, they evacuated together with the Greek corps to Thessaloniki, from where, in 5 months, they returned, after receiving the information about the occupation of the city by the Volunteer Army [8: 9].

Among the many reasons for the return, two main ones can be distinguished: 1) unsatisfactory living conditions in the mother country (most of the emigrants were placed in the unsettled camps for displaced persons) and, 2) the desire of wealthy Greeks to get back the property nationalized by the Bolsheviks and obtain the promised compensation after requisitions and nationalization.

To resolve the issue of compensation, on September 10,1919, Consul Stelio Vasiliadi, who was instructed to find out the damage suffered by the Greeks, arrived in Odessa on a special mission from the government of Greece [40]. Since Vasiliadi soon returned to performing the 
duties of Spain consul in Kiev, the issue of compensation in Odessa was resolving by Dutch Consul W. Muntz. Having returned to Odessa on September 24,1919, he faced a flow of requests and applications regarding the requisition of property, dwellings, and the restoration of lost documents.

To speed up the solution of those issues, the Greek Charitable Society, headed by rich Odessa merchant and the head of the Greek colony Eleftheri Pavlidi, established a special commission to analyze the claims. At the initiative of the commission, even a meeting on this issue was held with the city governor, as a result of which all Greek passports found in the administrative building were returned, the commission was given official rights to continue its work under the leadership of Wilhelm Muntz, and the taking back of requisitioned apartments and houses of Greek citizens began [26: 490-491; 31].

The Greeks also carried out a humanitarian mission to rescue the 'missing in action' members of the Greek expeditionary corps. For this, in the first half of November 1919, a Greek military mission headed by Lieutenant Meliant Atasonopulo arrived in Odessa. The mission had special instructions from the Greek government to gather in Odessa all the soldiers and officers of the Greek army "who stuck for some reason in Odessa, Nikolayev, Kherson, Kiev, and in the south of Russia". According to the information obtained by the mission, in the south of the former Russian Empire, there were many Greek soldiers who were taken prisoners or sick. To find them, the mission contacted the local military administrations "with a petition to assist in the return of Greek soldiers to their homeland" [20].

Many Greeks actively collaborated with the Volunteer Army. In 1919, Odessa Greek woman Ekaterina Snezhkova placed the Denikin Army Headquarters in her own mansion and housed the White Lieutenant Colonel Biryukov [12: 11]. Georgiy Surmeli, while studying at Nikolayev gymnasium, accepted an offer to collaborate with the White counter-intelligence as a secret agent and got an agent pseudonym 'Greek' [11:10-15]. The Nikolayev city dweller Paraskovya Kentros was a member of the White Army Aid Committee and participated in the collection of clothes, linen, and money for the volunteers [7:8].

Unlike urban communities, the rural community actively opposed the Volunteer Army and its policies. For example, Afanasiy Kiriyak, after moving to Odessa in 1919, joined the detachment of Grigoriy Kotovskiy [14: 9], and the representatives of the Nanaki family, who lived in the villages near Nikolayev, were the members of the Red partisan detachments [9:35-39]. The villagers formed detachments that fought armies of different political affiliations, boycotted mobilization, 
plundered landowners' estates, etc. It is not possible to highlight the attitude of the rural Greek community in more detail due to the lack of the necessary documentary data. At the same time, in the turbulent events of the First World War, revolution, and civil confrontation, the Greeks, like other peoples, found themselves in different camps, served different ideas, and espoused different doctrines.

On January 29,1920, the Reds occupied Kherson, and the next day - Nikolayev. Odessa was taken on February 8. With the first news of the advance of the Red Army, a significant number of Greeks decided to emigrate, or at least temporarily move to the Crimea, controlled by Wrangel's army. As a rule, the noble families, industrial and financial aristocracy, that is, the most active and educated strata of the Greek diaspora resorted to emigration. Representatives of such families as Arkas, Mavrokordato, Inglezi, Kuris, Petrokokino, Popandopulo, Rodokonaki, and many others left the Northern Black Sea region.

The Bolsheviks were true to their principles and after their return in 1920. The Regional Extraordinary Commissions and revolutionary tribunals with special zeal started looking for counter-revolutionaries. In the context of our paper, we would like to dwell on the case of Panat Serafidis, the secretary of the Greek Consulate.

On July 18, 1920, Odessa chekists arrested the 'spy White Guard organization' headed by P. Serafidis. Among the group's activists were: Odessa militiaman Arseniy Kiriliuk, uyezd chekist Dionisiy Petrato (Petrako), Serbian officer Aleksandr Komachevich (Kovalevich), Staff Captain Leonid Robu, Lieutenant of Denikin army Semen Golyasko and Nikolay Raftopulo (Ravtopulo), who was a courier between the organization and Wrangel headquarters. The organization joined together up to 300 people. The chekists confiscated large stocks of weapons, money, uniforms. By order of the collegium of Odessa Regional Extraordinary Commission, all the activists were shot [25].

Thus, the period of national revolutions and civil war left a heavy legacy. Omitting the issue of the destruction of industry and agriculture, communications and transport, the quantitative losses of the population of Ukraine, in particular, the Greeks, were unconditionally very heavy. The results of the study indicate that the greatest losses were suffered by the Greek community of the Northern Black Sea region as a result of the mass emigration of 1919-1920, and not as a result of civil confrontation or Bolshevik terror. If during 1918-1919 among the emigrants there was mostly the aristocracy, then in 1919-1920, together with the last units of the Entente and the White movement, all the strata of Greek society were leaving the Black Sea cities. The Greeks middle class and their social leaders paid the price for expression of their anti-Bolshevik 
opinion and support for the Greek troops participating in the Allied intervention in Ukraine (January - summer of 1919).

Greek position regarding the revolutionary events of 1917-1920 affected the fate of the Soviet Greeks during the Great Terror of 1937-1938 (the so-called "Greek Operation" of NKVD), when collaboration with the Austro-German administration, the support of the Greek contingent, and the Entente forces, participation in the White movement gave cause for accusations of counter-revolutionary activities and the subsequent imposition of death sentences.

\section{REFERENCES}

1.Avgitidis, K.G. (2003) Izdatel'skaya deyatel'nost' grekov Odessy (1829-1917) [Publishing activity of the Greeks of Odessa (1829-1917)]. Odessa: Astroprint.

2.Anon. (1918) Beseda komandovaniya minonostsev s konsulami. Nikolaev, 6 Dekabrya [Conversation of the destroyer command with the consuls. Nikolaev, December, 6]. Yuzhnoe slovo. 7th December.

3. Anon. (1918) Vyyizd konsuliv [Departure of consuls]. Nova Rada. 27th June (10th July).

4. The State Archive of Nikolaev Region. Fund R-5859. List 2. File 2161. Ikonomidi Angel Apostolovich, 1937-1957.

5. The State Archive of Nikolaev Region. Fund R-5859. List 2. File 2162. Ikonomidi Vladimir Angelovich, 1937-1998.

6. The State Archive of Nikolaev Region. Fund R-5859. List 2. File 2164. Iliopulos Leonid Anastasovich, 1937-1990.

7. The State Archive of Nikolaev Region. Fund R-5859. List 2. File 2313. Kentros Vasiliy Khristoforovich, 1937-1990.

8. The State Archive of Nikolaev Region. Fund R-5859. List 2. File 3155. Margelis Dmitriy Panayotovich, 1937-1990.

9. The State Archive of Nikolaev Region. Fund R-5859. List 2. File 3440. Nanaki Petr Vasil'evich, 1937-1958.

10. The State Archive of Nikolaev Region. Fund R-5859. List 2. File 3887. Popandopulo Leonid losifovich, 1933-1958.

11. The State Archive of Nikolaev Region. Fund R-5859. List 2. File 4630. Surmeli Georgiy Vladimirovich, 1938-1966.

12. The State Archive of Odessa Region. Fund R-8065. List 2. File 219. Snezhkova Ekaterina Antonovna, 1938-1994.

13. The State Archive of Odessa Region. Fund R-8065. List 2. File 2124. Georgiadi Idomentiy Pavlovich, 1937-1988.

14. The State Archive of Odessa Region. Fund R-8065. List 2. File 2319. Kiriyak Afanasiy Panayotovich, 1938-1991.

15. The State Archive of Odessa Region. Fund R-8065. List 2. File 2320. Yanopulo Anton Konstantinovich, 1937-1993. 
16. The State Archive of Odessa Region. Fund R-8065. List 2. File 2938. Sarlo Vladimir Panayotovich, 1937-1958.

17. The State Archive of Odessa Region. Fund R-8065. List 2. File 3224. Papafanasopulo Sof'ya Frantsevna, 1937-1959.

18. The State Archive of Odessa Region. Fund R-8065. List 2. File 6181. Buduris Stepan Khristovich, 1937-1989.

19. The State Archive of Odessa Region. Fund R-8065. List 2. File 8670. Stavriyani Mikhail Ivanovich, 1937-1989.

20. Anon. (1919). Grecheskaya missiya [Greek mission]. Odesskiy listok. 31st October (13th November). Nr. 163.

21. Anon. (1919) Zashchita grecheskikh poddannykh [Protection of Greek subjects]. Izvestiya Nikolaevskogo soveta rabochikh deputatov. 28th March. Nr. 5.

22. Izvestiya Nikolaevskogo soveta rabochikh, krasnoarmeyskikh i krasnoflotskikh deputatov. (1919) 4th July. Nr. 77.

23. Anon. (1919) Kn. D.G. Mavrokordato [Prince D.G. Mavrokordato]. Odesskiy listok. 13th (26th) October. Nr. 145.

24. Levchenko, L.L. (2019) Ukrayins'ka kampaniya grets'koyi armiyi 1919 r.: vplyv na podal'shu dolyu ukrayins'kykh grekiv (na prykladi Mykolaeva i Mykolayivshchyny) [Ukrainian Campaign of Greek Army in 1919: Its Influence on the Future of Ukrainian Greeks [The Case of Mykolayiv and Nearby Region]. Storinki istoriyi. 49. pp. 59-91. DOI: 10.20535/2307-5244.49.2019.189549

25. Anon. (1920) Likvidatsiya shpyguns'koyi bilogvardiys'koyi organizatsiyi [Liquidation of the White Guard Spy Organization]. Visti Odes'kogo Gubernial'nogo Revolyutsiynogo Komitetu. 20th July. Nr. 202.

26. Matyash, I. (2019) Inozemni predstavnytstva v Ukrayini (1917-1919 rr.): derzhavna misiya ta povsyakdennist' [Foreign missions in Ukraine (1917-1919): state mission and everyday life]. Kyiv: NAS of Ukraine.

27. Anon. (1918) Ob"yavlenie General'nogo germanskogo komandovaniya [Announcement of the German General Command]. Put' sotsial-demokrata. 24th July. Nr. 54.

28. Anon. (1918) Odesskie greki i soyuzniki [Odessa's Greeks and Allies]. Odesskie novosti. 14th November. Nr. 10841.

29. Odesskie novosti. (1919) 17th (30th) August. Nr. 10970.

30. Odesskiy listok. (1919) 21st August (3rd September). Nr. 94.

31. Anon. (1919) Osvobozhdenie grecheskikh kvartir [Clear of Greek Apartments]. Odesskie novosti. 18th (29th) November. Nr. 11061.

32. Anon. (1918) Ot"ezd konsulov [Departure of the consuls]. Odesskiy listok. 21st July. Nr. 147.

33.Anon. (1918) Ot"ezd soyuznykh konsulov [Departure of the allied consuls]. Odesskiy listok. 9th July (16th June). Nr. 137.

34. Anon. (1919) Revtribunal [Revolutionary Tribunal]. Izvestiya Odesskogo soveta rabochikh, krest'yanskikh i krasnoarmeyskikh deputatov. 4th June. Nr. 54.

35. Anon. (1919) Rozkryto monarkhichnu organizatsiyu [Disclosured Monarchical Organization]. Izvestiya Odesskogo Soveta rabochikh deputatov. 16th May. Nr. 37.

36. Savchenko,V. (2013) Proekt “Ukrayina”. Vol'naya Odessa - Odesskaya respub- 
lika - Yugo-Zapadnyy kray (1917-1919) [Project “Ukraine”. Free Odessa - Odessa Republic - South-Western Territory (1917-1919)]. Kharkiv: Folio.

37. Smoliy, V. (ed.) (2000) Greki na ukrayins'kykh terenakh: Narysy z etnichnoyi istoriyi. Dokumenty, materialy, karty [Greeks on Ukrainian lands: Essays on ethnic history. Documents, materials, maps]. Kyiv: Lybid'.

38. Anon. (1918) Soyuzni konsul'stva [Allied Consulates]. Nova Rada. 1st December. Nr. 227.

39. Anon. (1918) Strayk studentiv [Students Strike]. Nova Rada. 12th November. Nr. 211.

40. Anon. (1919) Temnaya istoriya [Dark Story]. Kievlyanin. 18th September (1st October). Nr. 19.

41. Tynchenko, Ya. (2007) Ofitsers'kyy korpus Armiyi Ukrayins'koyi Narodnoyi Respubliky (1917-1921) [Officer Corps of the Army of the Ukrainian People's Republic (1917-1921)]. Kyiv: Tempora.

42. Anon. (1919) Torzhestvennyy moleben [Solemn Prayer]. Yuzhnoe slovo. 8th March. Nr. 119.

43. Felshtinskiy, Yu. \& Chernyavskiy, G. (2013) Krasnyy terror v gody Grazhdanskoy voyny [Red Terror during the Civil War]. Moscow: Knizhnyy klub Knigovek.

44.Anon. (1919) Chervonyy sud [Red Court]. Izvestiya Odesskogo soveta rabochikh, krest'yanskikh i krasnoarmeyskikh deputatov. 25th June. Nr. 70.

45. Shyshko, O. (2019) Politychnyy teror bil'shovyts'koyi vlady v Odes'kiy guberniyi (sichen'1918 r. - berezen'1922 r.) [The Political Terror of the Bolshevik Power in Odessa Region (January 1918 - March 1922)]. Odesa: Osvita Ukrayiny.

46. Petsalis-Diomidis, N. (1972) Hellenism in Southern Russia and the Ukrainian Campaign: their effect on the Pontus Question (1919). Balkan Studies. 13(2). pp. 221-263.

47. Sifneos, E. (2018) Imperial Odessa. Peoples, Spaces, Identities. Leiden: Brill.

48. Avgitidis, K. (1999) I stratiotiki epemvasi ton kapitalistikon choron enantia sti Sovietiki Rosia kai i Ellada (1918-1920) [The military intervention of the capitalist countries against Soviet Russia and Greece (1918-1920)]. Athina: Synchroni Epochi.

49. Kostopoulos, T. (2019) I epanastasi ton bolsevikon me ta matia ton andron tou ellinikou ekstrateftikou somatos [The Bolshevik revolution through the eyes of the men of the Greek expeditionary corps]. [Online] Available from: https:// www.academia.edu/38988145 (Accessed: 25th September 2020).

\section{ЛИТЕРАТУРА}

1. Авгитидис К.Г. Издательская деятельность греков Одессы (1829-1917). Одесса: Астропринт, 2003.128 с.

2. Беседа командования миноносцев с консулами. Николаев, 6 декабря. // Южное слово. 1918. 7 дек. № 43.

3. Виїзд консулів // Нова Рада. 1918. 27 червня / 10 липня. № 110.

4. Государственный архив Николаевской области (ГАНО). Ф. Р-5859. 
Оп. 2. Д. 2161. Дело по обвинению Икономиди Ангела Апостоловича, 1937-1957 гг.

5. ГАНО. Ф. Р-5859. Оп. 2. Д. 2162. Икономиди Владимир Ангелович, 1937-1998 гг.

6. ГАНО. Ф. Р-5859. Оп. 2. Д. 2164. Илиопулос Леонид Анастасович, 1937-1990 гг.

7. ГАНО. Ф. Р-5859. Оп. 2. Д. 2313. Кентрос Василий Христофорович, 1937-1990 гг.

8. ГАНО. Ф. Р-5859. Оп. 2. Д. 3155. Маргелис Дмитрий Панайотович, $1937-1990$ гг.

9. ГАНО. Ф. Р-5859. Оп. 2.Д. 3440. Нанаки Петр Васильевич, 1937-1958 гг.

10. ГАНО. Ф. Р-5859. Оп. 2. Д. 3887. Попандопуло Леонид Иосифович, 1933-1958 гг.

11. ГАНО. Ф. Р-5859. Оп. 2. Д. 4630. Сурмели Георгий Владимирович, 1938-1966 гг.

12. Государственный архив Одесской области (ГАОО). Ф. Р-8065. Оп. 2. Д. 219. Снежкова Екатерина Антоновна, 1938-1994 гг.

13. ГАОО. Ф. Р-8065. Оп. 2. Д. 2124. Георгиади Идоментий Павлович, 1937-1988 гг.

14. ГАОО. Ф. Р-8065. Оп. 2. Д. 2319. Кирияк Афанасий Панайотович, 1938-1991 гг.

15. ГАОО. Ф. Р-8065. Оп. 2. Д. 2320. Янопуло Антон Константинович, 1937-1993 гг.

16. ГАОО. Ф. Р-8065. Оп. 2. Д. 2938. Сарло Владимир Панайотович, 1937 1958 гг.

17. ГАОО. Ф. Р-8065. Оп. 2. Д. 3224. Папафанасопуло Софья Францевна, $1937-1959$ гг.

18. ГАОО. Ф.Р-8065. Оп. 2.Д. 6181. Будурис Степан Христович, 1937-1989 гг.

19. ГАОО. Ф. Р-8065. Оп. 2. Д. 8670. Ставрияни Михаил Иванович, $1937-$ 1989 гг.

20. Греческая миссия // Одесский листок. 1919. 31 октября / 13 ноября. № 163.

21. Защита греческих подданных // Известия Николаевского Совета рабочих депутатов. 1919. 28 марта. № 5.

22. Известия Николаевского Совета рабочих, красноармейских и краснофлотских депутатов. 1919. 4 июля. № 77.

23. Кн. Д.Г. Маврокордато // Одесский листок. 1919. 13 / 26 окт. № 145.

24. Левченко Л.Л. Українська кампанія грецької армії 1919 р.: вплив на подальшу долю українських греків (на прикладі Миколаєва й Миколаївщини) // Сторінки історії. 2019. Вип. 49. С. 59-91. DOI: 10.20535/23075244.49.2019.189549

25. Ліквідація шпигунської білогвардійської організації // Вісти Одеського губерніального революційного комітету. 1920. 20 липня. № 202.

26. Матяш І. Іноземні представництва в Україні (1917-1919 рр.): державна місія та повсякденність. Київ: Інститут історії України НАН України, 2019. 556 c. 
27. Объявление Генерального германского командования // Путь социалдемократа. 1918. 24 июля. № 54.

28. Одесские греки и союзники // Одесские новости. 1918. 14 / 1 нояб. № 10841.

29. Одесские новости. 1919.17 (30) авг. № 10970.

30. Одесский листок. 1919. 21 августа / 3 сент. № 94.

31. Освобождение греческих квартир // Одесские новости. 1919.18 (29) нояб. № 11061.

32. Отъезд консулов // Одесский листок. 1918. 21 / 8 июля. № 147.

33. Отъезд союзных консулов // Одесский листок. 1918. 9 июля / 16 июня. № 137.

34. Ревтрибунал // Известия Одесского Совета рабочих, крестьянских и красноармейских депутатов. 1919. 4 июня. № 54.

35. Розкрито монархічну організацію // Известия Одесского Совета рабочих депутатов. 1919.16 мая.

36. Савченко В. Проект «Україна». Вольная Одесса - Одесская республика - Юго-Западный край (1917-1919). Харьков: Фолио, 2013. 283 с.

37. Смолій В. (ред.). Греки на українських теренах: Нариси з етнічної історії. Документи, матеріали, карти. Київ: Либідь, 2000. 488 с.

38. Союзні консульства // Нова Рада. 1918.1 грудня. № 227.

39. Страйк студентів // Нова Рада. 1918. 12 листопада. № 211.

40. Темная история // Киевлянин. 1919. 18 сент. / 1 окт. № 19.

41. Тинченко Я. Офіцерський корпус Армії Української Народної Республіки (1917-1921). Київ: Темпора, 2007. Кн.1. 536 с.

42. Торжественный молебен // Южное слово. 1919. 8 марта. № 119.

43. Фельштинский Ю., Чернявский Г. Красный террор в годы Гражданской войны. М.: Книжный клуб «Книговек», 2013. 432 с.

44. Червоний суд // Известия Одесского совета рабочих, крестьянских и красноармейских депутатов. 1919. 25 июня. № 70.

45. Шишко О. Політичний терор більшовицької влади в Одеській губернії (січень 1918 р. - березень 1922 р.). Одеса: «Освіта України», 2019. 340 с.

46. Petsalis-Diomidis N. Hellenism in Southern Russia and the Ukrainian Campaign: their effect on the Pontus Question (1919). Balkan Studies. 1972. Vol. 13, T. 2. P. 221-263.

47. Sifneos E. Imperial Odessa. Peoples, Spaces, Identities. Leiden: Brill, 2018. 286 p.

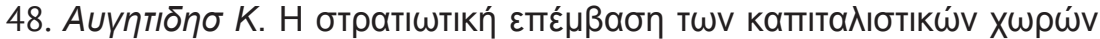

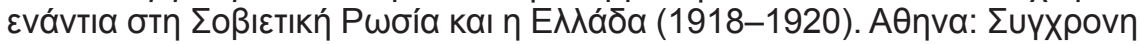
ЕтохП, 1999. 368 с.

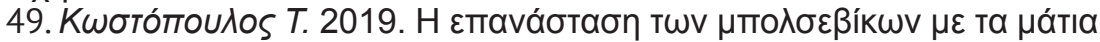

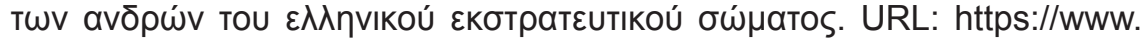
academia.edu/38988145 (дата обращения: 25.09.2020). 
Тригуб Александр Петрович - доктор исторических наук, профессор, заведующий кафедрой международных отношений и внешней политики Черноморского национального университета им. П. Могилы (Украина).

Oleksandr P. Trygub - Petro Mohyla Black Sea National University (Ukraine).

E-mail:alextrigub@ukr.net

Осипенко Александр Валентинович - кандидат исторических наук, старший преподаватель кафедры украиноведения, историко-правовых и языковых дисциплин Одесского национального морского университета (Украина).

Oleksandr V. Osypenko - Odessa National Maritime University (Ukraine).

E-mail: osupenkooleksandr@ukr.net 